\title{
Farewell to Harry M. Parker (1946-2019)
}

\author{
Stella Searston ${ }^{1}$ - Larry B. Smith ${ }^{2}$. \\ Georges Verly ${ }^{3}$
}

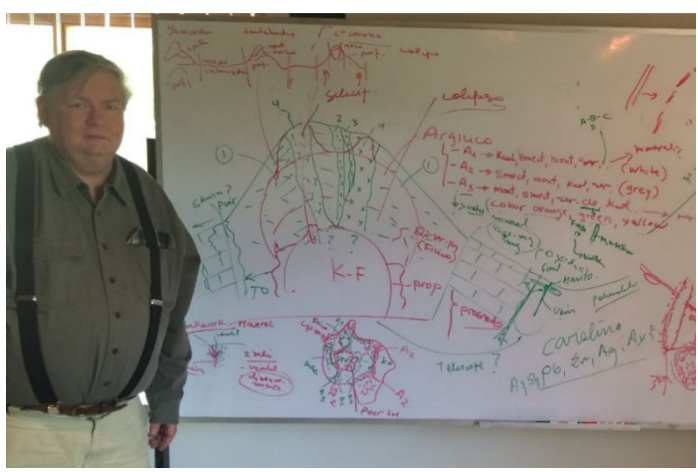

Harry M. Parker in 2018

Harry McDougal Parker passed away on 19 December, 2019, as a result of complications arising from melanoma cancer. Harry is survived by his wife Susan Kemper Parker, daughter Meg, son Winthrop, and six grand-daughters.

Harry was born in New York on 7 February, 1946. He spent his youth in the outdoors while his father worked for the US National Park Service as a ranger and naturalist.

Georges Verly

Georges.verly@woodplc.com

Larry B. Smith

lbmjsmith@charter.net

1 Mine Technical Services, 18124 Wedge Parkway, \#924, Reno, NV 89511, USA

2 Consultant Geologist, Reno, NV, USA

3 Wood Canada, Suite 400, 111 Dunsmuir Street, Vancouver, BC V6B 5W3, Canada 
Harry graduated from St Andrews High School, Middletown, Delaware in 1964. The school is best known for its portrayal in the film "Dead Poet's Society". His first degree was a B.Sc (honors) geology, from Stanford University, conferred in 1967. This was followed in 1969 by an AM in Geology, from Harvard. He then returned to Stanford in the early-1970s to obtain an MSc in statistics (1974), and a Ph.D. in geology (1975). His doctoral thesis was the second $\mathrm{PhD}$ awarded in geostatistics in the US.

From 1965 to 1975, in and around his studies, Harry worked for the Hanna Mining Company, with duties that ranged from grass-roots exploration to reserves estimation to mine geology. In late 1975, he joined Fluor Corporation, where he focused on resource and reserve estimation, audits, due diligence investigations and geostatistical analysis and problem-solving. He left Fluor in 1989 to co-found Mineral Resources Development Inc (MRDI), now part of the John Wood Group plc. MRDI provided Harry with seminal work experiences in the realms of resource estimation, expert witness testimonies, valuations, geostatistical analysis of geometallurgy, reconciliation, and considerations of resource classification. His wide-ranging commodity experience included $\mathrm{Cu}, \mathrm{Co}, \mathrm{Au}, \mathrm{Mo}, \mathrm{U}$, coal, oil shale, Ni, Fe, Mn, PGE, diamonds, K, Pb, Zn, $\mathrm{Ag}, \mathrm{Sn}$, and alumina.

Harry published more than 40 technical papers/presentations over the course of his career. His papers touched many of the most important aspects of Mineral Resource including geological controls, outliers, variography, recoverable reserves, conditional simulation, audits, reconciliation, classification, and geometallurgy. His first paper with Paul Switzer dealt with conditional probability distributions in ore reserve estimation. That was in 1975, when geostatistics was virtually unheard of in North America. Harry was instrumental in Andre Journel's move to North America when he was offered a visiting professorship in the mid-70 s at Stanford in the Department of Applied Earth Sciences and a half-time consultancy with Fluor. One year later, Andre was given a full time position at Stanford.

He was a member of an impressive number of societies and professional associations, amongst them the Society for Mining, Metallurgy and Exploration (SME), the Australasian Institute of Mining and Metallurgy (AusIMM), the Australian Institute of Geoscientists (AIG), Geological Society of America (GSA), Society of Economic Geologists (SEG), Institute of Materials, Minerals and Mining (IMMM), and the International Association for Mathematical Geosciences (IAMG). Harry was registered as a Professional Geologist in California, Arizona, and Minnesota.

Harry served with distinction on the Committee for Mineral Reserves International Reporting Standards (CRIRSCO) from 2007 to 2018, including as Deputy Chairman from 2013, Chairman from 2015 to 2016, and Past Chairman from 2016 to 2017. He was an integral part of the SME, serving as Chairman of the Registered Members Committee from 2007 to 2012; as co-Chairman of the Resources and Reserves Committee from 2007 to 2018; member of the SME Valuation Committee from 2012 to 2019; and on the SME Ethics Committee from 2013 to 2019, including as Chairman from 2015 to 2019. He was a driving force behind the development of the SME's 2017 edition of the Guide for Reporting Exploration Results, Mineral Resources, and Mineral Reserves.

Harry was renowned for his ability to form a bridge between different areas of expertise, including, in particular, geology, data collection, quality assurance and quality 
control, resource and reserve estimation, and metallurgy. His memory was legendary, he could remember minute details of studies completed dozen of years ago; this gave him great bench-marking ability. Harry liked catch-phrases, with "In general, an ounce of geology is worth a pound of geostatistics; this may be disappointing to geostatisticians with no geological background; tough", still being widely referenced. He never assumed, and checked everything, starting with the geological interpretation. His "boot camps" were for many a great training opportunity and a chance to get a grounding in what to look for, what to accept, and when to question other disciplines on data and interpretation.

In 2004, Journel and Kiriakidis dedicated their book on simulation approaches for mineral reserves to two unsung giants, one of them being Harry Parker. Maybe Harry was an unsung giant at the time, but not anymore, as the many awards he has received testify. He was awarded the AusIMM's Institute Medal in 2019, the SME's President's Citation in 2017, the SME's Award for Competence and Ethics in 2012, and the Southwest Mining Foundation's American Mining Hall of Fame Medal of Merit in 2007. He was made an Honorary Life Member of the Geostatistical Association of Australia, an Honorary Fellow of the Professional Society of the Independent Subsoil Experts of Kazakhstan, and an Honorary Representative of CRIRSCO. He also was conferred the Mongolian Best Geologist Award in 2015, and given APCOM Recognition Awards in 2015 and 2017. He was posthumously awarded the Harry M Parker Excellence Award and AIME/SME Saunders Award.

Harry worked all his life as a consultant. He was a model of integrity, hard work and technical achievement, earning him world-wide respect of his customers, colleagues and peers. He was always willing to give time to juniors and peers within the profession. He was at adept at communicating cutting-edge techniques as explaining the basics. He shared his knowledge and tools willingly. He was known for listening much, and speaking only when he had carefully decided what should be said-he could provide unvarnished opinions without offending. Harry was highly regarded for his knowledge, integrity, hard work, and new ideas, as much as his generosity, kindness, and respect.

\section{Selected Bibliography of Harry M. Parker}

1975 (with Switzer, P.) Use of conditional probability distributions in ore reserve estimation-A case study: 13th APCOM Symposium on Application of Computers and Operations Research in the Minerals Industry, Clausthal, Germany.

1976 (with Switzer, P.) The problem of ore versus waste discrimination for individual blocks, in Guarasscio, M., ed., Advanced Geostatistics in the Mining Industry: D. Reidel, https://doi.org/10.1007/978-94-0 10-1470-0_13.

1976 (with Sandefur, R.L.) A review of recent developments in geostatistics: 105th Annual AIME (American Institute of Mining, Metallurgical and Petroleum Engineers) Meeting, Las Vegas, Nevada, USA.

1978 (with Williams, C.E., and Ferguson, D.A.) Detailed surface mine planning of coal deposits by use of computer block models: 107th Annual AIME Meeting, Denver, Colorado, USA.

1979 (with Chavez, W.X.) The use of geostatistics in delineation of underground sandstone-type uranium deposits: 108th Annual AIME Meeting, New Orleans, Louisiana, USA.

1979 The volume variance relationship: A useful tool for mine planning: Engineering and Mining Journal, v. 180 , p. 106-123.

1984 Trends in geostatistics in the mining industry, in Verly, G., ed., Geostatistics for Natural Resources Characterization: D Reidel, https://doi.org/10.1007/978-94-009-3701-7_22. 
1984 (with Tooker, G.E., and Hartzell, D.R.) The use of computers for engineering mine modernization and development: Industrial Equipment and Materials, Coal Industry, v. VI,14 p. 1.

1988 (with Srivastava, R.M.) Robust measures of spatial continuity, in Armstrong, M., ed., Proceedings of the Third International Geostatistics Congress, 5-8 September 1988, Avignon, France: Springer, p. 295-306.

1990 Reserve estimation of uranium deposits, in Kennedy, B.A., ed., Surface Mining Handbook: Littleton, Colorado, USA, Society for Mining, Metallurgy and Exploration, 2nd edition, p. 355-375.

1991 Statistical treatment of outlier data in epithermal gold deposit reserve estimation: Mathematical Geology, v. 23, no. 2, p. 175-199, https://doi.org/10.1007/BF02066294.

1993 (with Rossi, M.E.) Estimating recoverable reserves: Is it hopeless? in Dimitrakopoulos, R., ed., Geostatistics for the Next Century: Kluwer Academic, p. 259-276.

1999 Ore reserve estimation for the new millennium: Proceedings, APCOM 99, Computer Applications in the Minerals Industries: 28th International Symposium, 20-22 October 1999, Colorado School of Mines, Golden, Colorado, USA.

2001 (with Stearley, R.D., Harrison, E.D., Maughan, J.E., Swenson, A.J., Switzer, J.E., Mudge, K.L., and Smith, T.C.) Evolution of computerized mine planning at Bingham Canyon Utah: Proceedings, APCOM 29th International Symposium, 25-27 April 2001, Beijing China.

2004 (with Murphy, M.P., Ross, A., and Audet, M.A.) Ore-thickness and nickel grade resource confidence at the Koniambo nickel laterite deposit in New Caledonia-A conditional simulation voyage of discovery, in Leuangthong, O., and Deutsch, C.V., eds., Geostatistics Banff 2004: Proceedings, 7th International Geostatistics Congress, Banff, Alberta, Canada, p. 468-478.

2006 Geological aspects of resource and reserve estimation, in Proceedings, SEG 2006: Wealth Creation in the Minerals Industry, Keystone, Colorado, USA: Society of Economic Geologists.

2007 (with Kirkland, K.M., Gurtler, D., Lipten, E.J., Brettschneider, A., and Gomez, P.) Block valuation at Antamina Mine: APCOM 2007, 33rd International Symposium on Application of Computers and Operations Research in the Mineral Industry.

2014 Reconciliation principles for the mining industry, in Mineral Resource and Ore Reserve Estimation, the AusIMM guide to good practice: Australasian Institute of Mining and Metallurgy, p. 721-737.

2014 (with Dohm C.) Evolution of Resource Classification from 1980 to 2014 and current best practice:, Julius Werner Lecture, IMMM, PowerPoint, 69 pp.

2014 (with Verly G. and Postolski T.) Assessing Uncertainty with Drill Hole Spacing Studies-Applications to Mineral Resources, Orebody Modelling and Strategic Mine Planning Symposium, Ed. Dimitrakopoulos, Perth, WA, pp. 109-118.

2015 (with Hill, E., and Morgan, R.) Comparison of Fort Knox gold deposit resources from Pre-feasibility study (1991) to production (1997 to 2015): 37th APCOM Symposium, PowerPoint, 68 p.

2017 (with Brisebois, K., Vela, I., and Pablo, M.) Optimized Project Targeting using Conditional Simulation Post-processing for the Los Sulfatos Underground Porphyry Copper Project in Chile: APCOM 2017, 38th International Symposium on Application of Computers and Operations Research in the Mineral Industry, Colorado School of Mines, Golden, Colorado USA, 9-11 August 2017, 11 p.

2017 (with Verly G., Artica C., Kim H., and Bortoletto Machado E.L.) Classification and Dilution Study by Simulation of a Large Copper Deposit, Peru. Proceedings of the 38th APCOM International Symposium, Ed. Dagdelen K, pp. K-11-K-18.

2017 (with Yue, T., Roper, G., Deutscher, J., Berthelsen, D., and Pelletier, C.) Geometallurgy at Mount Milligan Mine-A Voyage of Discovery: MGMI (Indonesian Society of Economic Geologists) Annual Convention, p. 29-50. 